\title{
Editorial
}

\section{DISSIDÊNCIAS DE GÊNERO E SEXUALIDADE NAS LITERATURAS DE LÍNGUA PORTUGUESA}

\author{
Aline da Silva Lopes \\ Edson Salviano Nery Pereira \\ Esdras Soares da Silva \\ José Victor Nunes Mariano \\ Oluwa-Seyi Salles Bento ${ }^{7}$ \\ Helder Thiago Maia ${ }^{2}$
}

Questões de gênero e sexualidade têm sido recorrentemente utilizadas, seja sob o signo da perversão, da pornografia, da moralidade, seja sob o signo de uma suposta falta de qualidade estética, pela crítica e pela historiografia literária, como critérios, ainda que não declarados, para o silenciamento e o apagamento de obras e autores que desterritorializam as cisheteronormatividades de gênero e sexualidade ${ }^{3}$. Nesse sentido, é preciso afirmar que, assim como o cânone literário, critérios estéticos canônicos são também critérios masculinos, brancos, cisgêneros e heteronormativos.

Mesmo quando a literatura foi reticente em abordar essas personagens, mesmo quando a literatura deu as mãos à medicina na patologização e psiquiatrização dessas personagens, mais pragmáticos ainda, em sua tarefa de manter no armário algumas dessas narrativas, foram a crítica e a historiografia literária ${ }^{4}$. Nesse contexto, os textos selecionados para esse dossiê entram nas disputas narrativas que insistem em produzir respiros e rachaduras nos campos teóricos e críticos da literatura que não cansam de nos soterrar.

Assim sendo, nessa vigésima quarta edição da Revista Crioula, número este que no Brasil carrega a marca dos sonhos de extermínio (Giorgi, 2004), que recorda as violências homolesbotransfóbicas, mas que também sugere luta e resistência, apresentamos dezenove artigos e três entrevistas que discutem e problematizam o lugar das dissidências de gênero e sexualidade nas literaturas, nas artes e na crítica literária. Para isto, o dossiê se abre ao leitor com um artigo-mestre do professor Rafael M. Mérida Jiménez sobre autobiografias trans.

Em seguida, há um bloco de textos que discutem as homossexualidades masculinas e femininas

\footnotetext{
1 Alunos do Programa de Pós-Graduação em Estudos Comparados de Literaturas de Língua Portuguesa, do Departamento de Letras Clássicas e Vernáculas, da Faculdade de Filosofia, Letras e Ciências Humanas da Universidade de São Paulo (FFLCH/USP).

2 Pós-Doutorando no Programa de Pós-Graduação em Estudos Comparados de Literaturas de Língua Portuguesa, do Departamento de Letras Clássicas e Vernáculas, da Faculdade de Filosofia, Letras e Ciências Humanas, da Universidade de São Paulo (FFLCH/USP). Bolsista de pós-doutoramento FAPESP.

3 Sobre isto ver, por exemplo, o capítulo "A morte dos vagalumes queer ou a grande luz da historiografia literária” (MAIA, 2014).

$4 \quad$ Sobre isto ver, por exemplo, Jorge Vergara (2018)
} 
a partir principalmente dos textos literários de Waldo Motta, Francisco Mallmann, Tulio Carella (reivindicado aqui também como parte da literatura brasileira), Victor Heringer, Cassandra Rios e Dinorath do Valle, além disso há também uma interessante discussão sobre a figura do michê na literatura a partir de vários autores brasileiros.

Em outro bloco de textos, aproximamos aqueles que estão interessados em discutir, principalmente, questões que envolvem dissidências e normatividades de gênero. Nesse sentido, os artigos analisam principalmente obras de Afonso Reis Cabral, Conceição Evaristo, Hilda Hilst, Paulina Chiziane, José Eduardo Agualusa, Virgílio de Lemos, Lidia Jorge e Isabela Figueiredo. Além disso, há um artigo que discute a violência contra travestis a partir de vários autores brasileiros e outro que discute a potência política e estética da arte $d r a g$.

Por fim, o dossiê também conta com três entrevistas, a primeira delas com a Natalia Borges Polesso sobre literatura lésbica, outra com Amara Moira sobre literatura trans e outra com Maria Valéria Rezende sobre a obra da referida autora.

Essa edição conta, ainda, com uma sessão de textos livres, a qual apresenta um texto que discute questões de literatura e ensino, a partir da canção de Baden Powell e Vinícius de Moraes. Outro texto, aborda aspectos históricos e culturais, valendo-se da obra da escritora moçambicana Paulina Chiziani. A resenha sobre o livro de poemas e pinturas de Candido Portinari.

\section{Referências}

GIORGI, Gabriel. Sueños de exterminio: homosexualidad y representación en la literatura argentina contemporánea. Rosario: Beatriz Viterbo, 2004.

MAIA, Helder Thiago Cordeiro. Devir Darkroom e a Literatura Hispano-Americana. Rio de Janeiro: Multifoco, 2014.

VERGARA, JORGE. Toda canção de liberdade vem do cárcere: homofobia, misoginia e racismo na recepção da obra de Mário de Andrade. Tese (Doutorado em Música) - Universidade Federal do Estado do Rio de Janeiro, Rio de Janeiro, 2018. 